\title{
Wolbachia is present in the European grapevine moth
}

\author{
Marlon Pazian ｜ Elisa Bacala | Fernando T. Rei | Tânia Nobre (iD
}

MED-Mediterranean Institute for Agriculture, Environment and Development, Instituto de Investigação e Formação Avançada, Universidade de Évora, Pólo da Mitra, Portugal

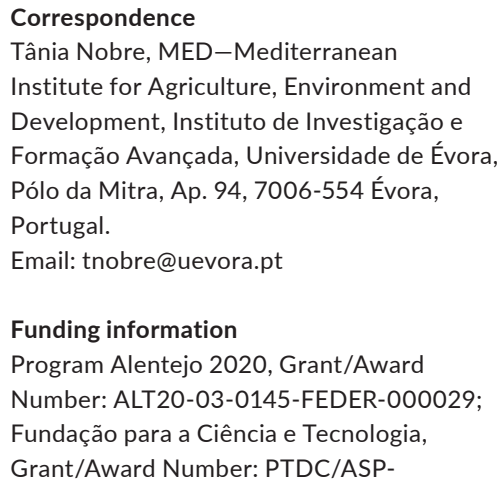

\begin{abstract}
The European grapevine moth, Lobesia botrana, has high economic impact on grapevines being one of the most harmful pests of vineyards worldwide. Wolbachia infection has not yet been reported for this moth. We systematically look for Wolbachia presence in L. botrana from three areas within the viticultural region of Alentejo (Portugal), via wsp gene specific PCR, and consistently found its presence. The interaction between the grapevine, its associated moth pest and the Wolbachia needs to be further explored, towards its potential in the development of symbiosis-based pest management strategies.
\end{abstract}

KEYWORDS

Lobesia botrana, pest management, specific PCR, symbiosis, vineyard, wsp gene

\section{1 | INTRODUCTION}

Directly associated with grapevine, the European grapevine moth-Lobesia botrana (Denis and Schiffermüller) (Lepidoptera: Tortricidae)-is actually a polyphagous insect able to develop and complete its life cycle on several host plants (e.g. loriatti et al., 2011; Thiéry \& Moreau, 2007). Despite the diversity of possible host plants, it is on the cultivated Vitis vinifera that $L$. botrana encounters its main food resource, giving it the title of one of the most harmful pests of vineyards worldwide (Thiéry et al., 2018).

The impact of this pest on grapevines has been considered high, with relevant yield losses being reported in a wide geographic range (Delbac \& Thiéry, 2016; Moschos, 2006; Thiéry et al., 2018). As other crops, vineyards also face the need of a drastic reduction in pesticide use, paired with the challenges arising from invasion by new pests/ diseases and climate change. The use of broad-spectrum insecticides (e.g. pyrethroids, carbamates and organophosphates) are linked to high environmental impacts and its toxicological aspects are triggering the search for alternatives, such as microbial and botanical pesticides (Pertot et al., 2016), but are also fuelling the search on behaviour-modifying chemicals (loriatti et al., 2011) and efficient biological control agents (Thiéry et al., 2018).

Several natural enemies have been suggested for L. botrana, varying in time and space (e.g. Moreau, Buffenoir, Thiéry, \&
Vogelweith, 2019; Moreau, Villemant, Benrey, \& Thiéry, 2010; Xuéreb \& Thiéry, 2006) including entomopathogenic fungi (Altimira et al., 2019; López-Plantey et al., 2019; Sammaritano et al., 2018). As to bacteria, mainly Bacillus thuringiensis has been used to control the European grapevine moth (Escudero, Estela, Escriche, \& Caballero, 2007; Ifoulis \& Savopoulou-Soultani, 2004; Ioriatti et al., 2011). However, multiple approaches are becoming available for insect pest control founded on manipulation of microbial partners (reviewed in Arora \& Douglas, 2017), considering bacteria both entangled in a transient or in a persistent relationship with the insect host. One of the best-known bacterial group associated with insects with recognised potential in pest management is the Wolbachia, a group of obligatory intracellular and maternally inherited bacteria (Bourtzis, 2008).

Wolbachia presence is known to induce reproductive changes in hosts, causing decrease in fertility or even impairing reproduction-through male killing, feminisation, parthenogenesis induction or cytoplasmic incompatibility (e.g. Baldo, Lo, \& Werren, 2005; Hurst et al., 1999; Kikuchi \& Fukatsu, 2003; Saridaki \& Bourtzis, 2010; Zchori-Fein \& Bourtzis, 2011). Wolbachia can (but not always does) influence insects' pesticide sensitivity, altering its susceptibility (Li, Liu, \& Guo, 2018; Liu \& Guo, 2019). In the quest to develop efficient and target-specific pest management strategies, Wolbachia-based technologies have been widely discussed (e.g. Apostolaki et al., 2011; 
Bourtzis, 2008; Crotti et al., 2012; Doudoumis et al., 2013; Floate et al., 2007) and one of the most iconic examples concerns the control of arboviral disease transmission by Aedes aegypti mosquitoes (World Mosquito Program; www.worldmosquitoprogram.org). In Lepidoptera, most references concern the moth Ephestia kuehniella, a cosmopolitan pest of stored products such as flour, where it was found to induce cytoplasmic incompatibility, lower fertile sperm transfer or probably male killing (e.g. Ikeda, Ishikawa, \& Sasaki, 2011; Lewis, Champion De Crespigny, Sait, Tregenza, \& Wedell, 2011; Sumida, Katsuki, Okada, Okayama, \& Lewis, 2017; Fujii et al., 2001). Nonetheless, the first step is accessing whether the target pest population is naturally Wolbachia-infected or not.

For L. botrana, to the best of our knowledge, no systematic search for Wolbachia infection was performed and the only work found reported negative results (Zchori-Fein \& Perlman, 2004), suggesting that this moth would not be associated with this bacterial group. Our findings, comprising L. botrana specimens from three sampling areas within the viticultural region of Alentejo (Portugal), show the widespread presence of Wolbachia in the European grapevine moth. This association needs to be further understood and we should start looking for potential effects of the interaction on $L$. botrana feeding choices, reproduction and overall fitness that might affect the grapevine as selected host plant.

\section{2 | MATERIAL AND METHODS}

Lobesia botrana was sampled in three vineyards in the Alentejo region (Figure 1a) by means of commercial sticky traps with specific pheromones (Biosani). Per sampling location, 20 morphological identified specimens were removed from the trap and conserved in ethanol $96 \%$ at $-20^{\circ} \mathrm{C}$. Individuals were allowed to dry on filter paper prior to DNA extraction (NZY Tissue gDNA Isolation kit, from NZYTech, Lda). All extraction products were stored at $-20^{\circ} \mathrm{C}$ and later used directly in the PCR.

For host species confirmation, a fragment of the cytochrome c oxidase subunit I (COI) gene was amplified using the primers LCO1490 (5'-GGT CAA CAA ATC ATA AAG ATA TTG G-3' and
HCO2198 (5'-TAA ACT TCA GGG TGA CCA AAA AAT CA-3') (Folmer, Black, Hoeh, Lutz, \& Vrijenhoek, 1994) and the protocol described in Nobre, Gomes, and Rei (2018). The purified PCR product (NZYGelpure kit from NZYTech, Lda) was commercially sequenced (Macrogen Inc.).

For Wolbachia presence, wsp gene specific PCRs were performed ( 2 technical-replicates) using the primers WSP1 (5'-GGG TCC AAT AAG TGA TGA AGA AAC - $3^{\prime}$ ) and WSP2 (5'-TTA AAA CGC TAC TCC AGC TTC TGC-3') (Zhou \& Neill, 1998). PCR conditions were $94^{\circ} \mathrm{C}$ for $5 \mathrm{~min} ; 35 \mathrm{cycles}$ of $94^{\circ} \mathrm{C}$ for $30 \mathrm{~s}, 55^{\circ} \mathrm{C}$ for $30 \mathrm{~s}, 72^{\circ} \mathrm{C}$ for $1 \mathrm{~min}$ and $72^{\circ} \mathrm{C}$ for $10 \mathrm{~min}$ and $20 \mathrm{ng}$ of gDNA, Buffer $1 \mathrm{X}, \mathrm{MgCl} 21.5 \mathrm{mM}$, dNTP $0.04 \mathrm{mM}$, primers $0.2 \mu \mathrm{M}$, DNA polymerase $1 \mathrm{U}$ (NZYTaq II DNA polymerase, from NZYTech, Lda). For confirmation of procedure specificity and guarantees of amplification of the desired final product, two randomly selected PCR products, per sampling location, were purified and sequenced as above. PCR products of the expected size $(0.6 \mathrm{~kb})$ were double digested with the restriction endonucleases Dral and BseCl (Kikuchi \& Fukatsu, 2003; according to producers' protocol), electrophoresed on a $2 \%$ TAE-agarose and the pattern was registered.

\section{3 | RESULTS}

We confirmed the analysed specimens as belonging to Lobesia botrana (Genbank Accesion number MT233430). Not all the samples were successfully amplified; only the samples positive for COI were used in the detection of Wolbachia, decreasing the probability of false negatives. Wolbachia infection was detected in 47 of the 55 specimens examined (17/18 from Reguengos, 18/19 from Redondo and 12/18 from Cuba, see Figure 1). The wsp gene segments subjected to RFLP typing showed only one pattern type (Figure $1 \mathrm{~b}$ ) and the sequenced amplicons had the exact same nucleotide composition (Genbank Accession numbers MT228045, MT228046 and MT228047 for each population consensus), with the highest level of similarity with Wolbachia endosymbiont of Tetranychus urticae (but also of Pieris rapae, Jalmenus evagoras and Paratrechina longicornis) outer surface protein gene (100\% similarity in a total query cover; GenBank BLAST). (a)

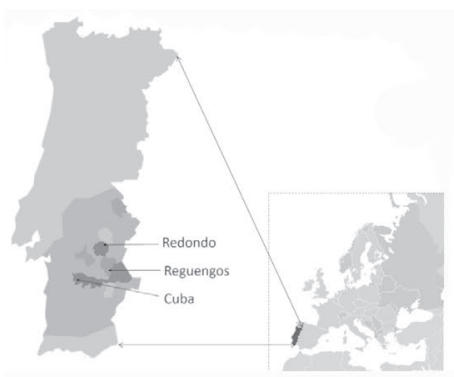

(b)

(b1)

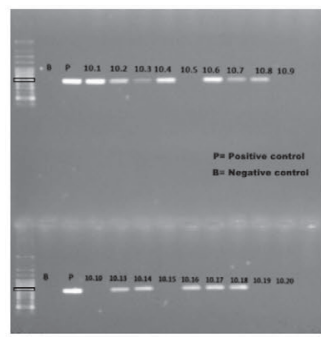

(b2)

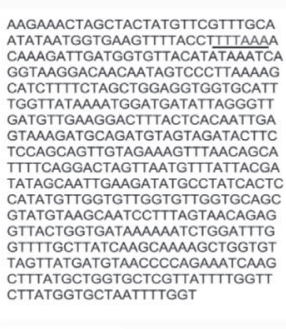

(b3)

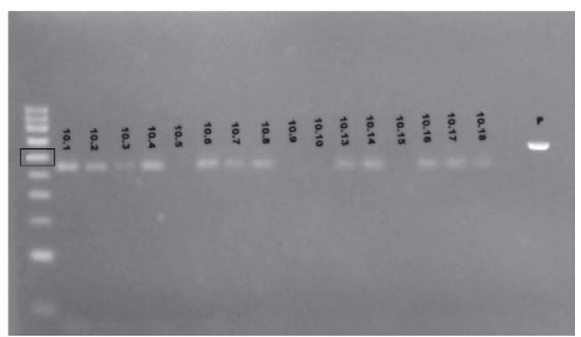

FIGURE 1 (a) Location of the three sampled vineyards, within the region Alentejo (darker grey); the grey shades correspond to the different wine regions. (b) Detection of wsp gene. (b1) Gel of wsp PCR specific amplicon, (b2) wsp consensus sequence and restriction sites of the endonucleases Dral (underlined), (b3) RFLP pattern resulting of the product digestion with the restriction endonucleases. Rectangle indicates $0.6 \mathrm{~Kb}$ band 


\section{4 | DISCUSSION}

Even though it is estimated that about $80 \%$ of Lepidoptera species are hosts of Wolbachia (Ahmed, Araujo-jnr, Welch, \& Kawahara, 2015) this is, to the best of our knowledge, the first study confirming its presence in the European grape moth, Lobesia botrana. It should be acknowledged, however, that the infection level here reported might be affected by false negative or positive results, as those have been reported for wsp gene PCR-based amplification (e.g. Carvajal, Hashimoto, Harnandika, Amalin, \& Watanabe, 2019; Jeyaprakash \& Hoy, 2000).

It is estimated that lepidopteran species harbour more than 90 different Wolbachia strains, with high incidence of identical and multiple strains of Wolbachia among butterflies and moths and evidence of common horizontal transmission (Ahmed, Breinholt, \& Kawahara, 2016). As such, finding Wolbachia in the European grape moth is not surprising, but it can have an impact in terms of pest management strategies, triggering a new research line.

Ahmed et al. (2015) found no correlation between Wolbachia infection frequency and phylogenetic relatedness of lepidopteran hosts but a significant correlation between infection and host geography. Inter-specific, inter-familial and inter-ordinal horizontal transmission is also common (Ahmed et al., 2016). Bringing these facts together it is not surprising that the Wolbachia wsp strain here sequenced seems to be the same reported infecting the mite Tetranychus urticae in Portugal (Zélé, Weill, \& Magalhães, 2018). Also, vector-mediated inter-specific transmission was observed in Wolbachia through shared food sources (e.g. Huigens, Almeida, Boons, Luck, \& Stouthamer, 2004; Oliver, Degnan, Burke, \& Moran, 2010; Sintupachee, Milne, Poonchaisri, Baimai, \& Kittayapong, 2006), ectoparasitic mites (Gehrer \& Vorburger, 2012; Jaenike, Polak, Fiskin, Helou, \& Minhas, 2007) and parasitoids (Ahmed et al., 2015).

In Lepidoptera, Wolbachia is known to manipulate host reproduction through male killing, feminization and cytoplasmic incompatibility and although these strategies favour the maintenance of the endosymbiont in the host population, they also impact on host biology and evolution (reviewed in Duplouy \& Hornett, 2018). A highly distorted female biased sex ratio has nonetheless an obvious consequence: many females remain unmated affecting the host reproductive success. This unbalance could potentially be exploited in the developing of new, highly targeted, pest management approaches. The peculiarities of the Lepidoptera sex determination system, where the female is the heterogametic sex, leads to specificities in mechanisms and repercussions of Wolbachia induced reproductive manipulations (Duplouy \& Hornett, 2018) that need to be understood. The identification of abundant Wolbachia infection levels in the target pest species is just a first and needed step towards the development of new symbiosis-based pest management strategies.

\section{ACKNOWLEDGEMENT}

The research was funded by Program Alentejo 2020; project "A Protecção Integrada do olival alentejano. Contributos para a sua inovação e melhoria contra os seus inimigos-chave" Reference: ALT20-03-0145-FEDER-000029. TN was supported by PTDC/ ASP-PLA/30650/2017 ("Fundação para a Ciência e Tecnologia", FCT Portugal).

\section{CONFLICTS OF INTEREST}

The authors declare no conflict of interest.

\section{AUTHOR CONTRIBUTIONS}

Conceptualization, T.N.; methodology, M.P., E.B. and T.N.; formal analysis, M.P.; resources, F.T.R. and T.N.; writing-original draft preparation, M.P. and T.N.; writing-review and editing, M.P. and T.N.; supervision, T.N.; funding acquisition, F.T.R. All authors have read and agreed to the published version of the manuscript.

\section{DATA AVAILABILITY STATEMENT}

The data that support the findings of this study are openly available in Genbank ${ }^{\circledR}$ at https://www.ncbi.nlm.nih.gov/genbank/, with the accession numbers MT233430, MT228045, MT228046 and MT228047. Gel images will be made available from the corresponding author upon request.

\section{ORCID}

Tânia Nobre (iD https://orcid.org/0000-0002-1855-7451

\section{REFERENCES}

Ahmed, M. Z., Araujo-Jnr, E. V., Welch, J. J., \& Kawahara, A. Y. (2015). Wolbachia in butterflies and moths: Geographic structure in infection frequency. Frontiers in Zoology, 12(1), 1-9. https://doi.org/10.1186/ s12983-015-0107-z

Ahmed, M. Z., Breinholt, J. W., \& Kawahara, A. Y. (2016). Evidence for common horizontal transmission of Wolbachia among butterflies and moths. BMC Evolutionary Biology, 16(1), 1-16. https://doi. org/10.1186/s12862-016-0660-x

Altimira, F., De La Barra, N., Rebufel, P., Soto, S., Soto, R., Estay, P., ... Tapia, E. (2019). Potential biological control of the pupal stage of the European grapevine moth Lobesia botrana by the entomopathogenic fungus Beauveria pseudobassiana in the winter season in Chile. BMC Research Notes, 12, 548. https://doi.org/10.1186/ s13104-019-4584-6

Apostolaki, A., Livadaras, I., Saridaki, A., Chrysargyris, A., Savakis, C., \& Bourtzis, K. (2011). Transinfection of the olive fruit fly Bactrocera oleae with Wolbachia: Towards a symbiont-based population control strategy. Journal of Applied Entomology, 135(7), 546-553. https://doi. org/10.1111/j.1439-0418.2011.01614.x

Arora, A. K., \& Douglas, A. E. (2017). Hype or opportunity? Using microbial symbionts in novel strategies for insect pest control. Journal of Insect Physiology, 103, 10-17. https://doi.org/10.1016/j.jinsphys.2017.09.011

Baldo, L., Lo, N., \& Werren, J. H. (2005). Mosaic nature of the Wolbachia surface protein. Journal of Bacteriology, 187(15), 5406-5418. https:// doi.org/10.1128/JB.187.15.5406-5418.2005

Bourtzis, K. (2008). Wolbachia-based technologies for insect pest population control. In S. Aksoy (Ed.), Transgenesis and the management of vector-borne disease. Advances in experimental medicine and biology (pp. 104-113). New York, NY: Springer.

Carvajal, T. M., Hashimoto, K., Harnandika, R. K., Amalin, D. M., \& Watanabe, K. (2019). Detection of Wolbachia in field collected Aedes aegypti mosquitoes in metropolitan Manila, Philippines. Parasites \& Vectors, 12(1), 1-9. https://doi.org/10.1186/s13071-019-3629-y 
Crotti, E., Balloi, A., Hamdi, C., Sansonno, L., Marzorati, M., Gonella, E., ... Daffonchio, D. (2012). Microbial symbionts: A resource for the management of insect-related problems. Microbial Biotechnology, 5(3), 307-317. https://doi.org/10.1111/j.1751-7915.2011.00312.x

Delbac, L., \& Thiéry, D. (2016). Damage to grape flowers and berries by Lobesia botrana larvae (Denis \& Schiffernüller) (Lepidoptera: Tortricidae), and relation to larval age. Australian Journal of Grape and Wine Research, 22(2), 256-261. https://doi.org/10.1111/ ajgw.12204

Doudoumis, V., Alam, U., Aksoy, E., Abd-Alla, A. M. M., Tsiamis, G., Brelsfoard, C., ... Bourtzis, K. (2013). Tsetse-Wolbachia symbiosis: Comes of age and has great potential for pest and disease control. Journal of Invertebrate Pathology, 112, S94-S103. https://doi. org/10.1016/j.jip.2012.05.010

Duplouy, A., \& Hornett, E. A. (2018). Uncovering the hidden players in Lepidoptera biology: The heritable microbial endosymbionts. PeerJ, 6, 1-45. https://doi.org/10.7717/peerj.4629

Escudero, I. R., Estela, A., Escriche, B., \& Caballero, P. (2007). Potential of the Bacillus thuringiensis toxin reservoir for the control of Lobesia botrana (Lepidoptera: Tortricidae), a major pest of Grape plants potential of the Bacillus thuringiensis toxin reservoir for the control of Lobesia botrana (Lepidoptera: Tortricidae), a Major Pest of Grape Plants. Applied and Environmental Microbiology, 73, 337-340. https:// doi.org/10.1128/AEM.01511-06

Floate, K. D., Kyei-Poku, G. K., \& Coghlin, P. C. (2007). Overview and relevance of Wolbachia bacteria in biocontrol research. Biocontrol Science and Technology, 16(8), 767-788. https://doi.org/10.1080/0958315060 0699606

Folmer, O., Black, M., Hoeh, W., Lutz, R., \& Vrijenhoek, R. (1994). DNA primers for amplification of mitochondrial cytochrome $c$ oxidase subunit I from diverse metazoan invertebrates. Molecular Marine Biology and Biotechnology, 3, 294-297.

Fujii, Y., Kageyama, D., Hoshizaki, S., Ishikawa, H., \& Sasaki, T. (2001). Transfection of Wolbachia in Lepidoptera: The feminizer of the adzuki bean borer Ostrinia scapulalis causes male killing in the Mediterranean flour moth Ephestia kuehniella. Proceedings of the Royal Society of London. Series B, Biological Sciences, 268, 855-869. https://doi.org/10.1098/rspb.2001.1593

Gehrer, L., \& Vorburger, C. (2012). Parasitoids as vectors of facultative bacterial endosymbionts in aphids. Biology Letters, 8(4), 613-615. https://doi.org/10.1098/rsbl.2012.0144

Huigens, M. E., Almeida, R. P., Boons, P. A. H., Luck, R. F., \& Stouthamer, R. (2004). Natural interspecific and intraspecific horizontal transfer of parthenogenesis-inducing Wolbachia in Trichogramma wasps. Proceedings of the Royal Society of London. Series B, Biological Sciences, 271(1538), 509-515. https://doi.org/10.1098/rspb.2003.2640

Hurst, G. D. D., Jiggins, F. M., Von Der Schulenburg, J. H. G., Bertrand, D., West, S. A., Goriacheva, I. I., ... Majerus, M. E. N. (1999). Male-killing Wolbachia in two species of insect. Proceedings of the Royal Society of London. Series B, Biological Sciences, 266(1420), 735. https://doi. org/10.1098/rspb.1999.0698

Ifoulis, A. A., \& Savopoulou-Soultani, M. (2004). Biological control of Lobesia botrana (Lepidoptera: Tortricidae) larvae by using different formulations of Bacillus thuringiensis in 11 vine cultivars under field conditions. Journal of Economic Entomology, 97(2), 340-343. https:// doi.org/10.1093/jee/97.2.340

Ikeda, T., Ishikawa, H., \& Sasaki, T. (2011). Infection density of Wolbachia and level of cytoplasmic incompatibility in the Mediterranean flour moth, Ephestia kuehniella. Journal of Invertebrate Pathology, 84(2003), 1-5. https://doi.org/10.1016/S0022-2011(03)00106-X

Ioriatti, A. C., Anfora, G., Tasin, M., De Cristofaro, A., Witzgall, P., \& Lucchi, A. (2011). Chemical ecology and management of Lobesia botrana (Lepidoptera: Tortricidae). Journal of Economic Entomology, 104(4), 1125-1137. https://doi.org/10.1603/EC10443
Jaenike, J., Polak, M., Fiskin, A., Helou, M., \& Minhas, M. (2007). Interspecific transmission of endosymbiotic Spiroplasma by mites. Biology Letters, 3(1), 23-25. https://doi.org/10.1098/rsbl.2006.0577

Jeyaprakash, A., \& Hoy, M. A. (2000). Long PCR improves Wolbachia DNA amplification: Wsp sequences found in $76 \%$ of sixty-three arthropod species. Insect Molecular Biology, 9(4), 393-405. https://doi. org/10.1046/j.1365-2583.2000.00203.x

Kikuchi, Y., \& Fukatsu, T. (2003). Diversity of Wolbachia endosymtions in heteroptan bugs. Applied and Environmental Microbiology, 69(10), 6082-6090. https://doi.org/10.1128/AEM.69.10.6082

Lewis, Z., Champion De Crespigny, F. E., Sait, S. M., Tregenza, T., \& Wedell, N. (2011). Wolbachia infection lowers fertile sperm transfer in a moth. Biology Letters, 7, 187-189. https://doi.org/10.1098/ rsbl.2010.0605 https://

Li, Y., Liu, X., \& Guo, H. (2018). Variations in endosymbiont infection between buprofezin-resistant and susceptible strains of Laodelphax striatellus (Fallén). Current Microbiology, 75(6), 709-715. https://doi. org/10.1007/s00284-018-1436-x

Liu, X. D., \& Guo, H. F. (2019). Importance of endosymboints Wolbachia and Rickettsia in insect resistance development. Current Opinion in Insect Science, 33, 84-90. https://doi.org/10.1016/j. cois.2019.05.003

López-Plantey, R., Papura, D., Couture, C., Thiéry, D., Pizzuolo, P. H., Bertoldi, M. V., \& Lucero, G. S. (2019). Characterization of entomopathogenic fungi from vineyards in Argentina with potential as biological control agents against the European grapevine moth Lobesia botrana. BioControl, 64, 501-511. https://doi.org/10.1007/ s10526-019-09955-z

Moreau, J., Buffenoir, N., Thiéry, D., \& Vogelweith, F. (2019). Lobesia botrana as a preferred host of Campoplex capitator, the most occurring larval parasitoid in European vineyards. Entomologia Generalis, 39(3), 307-312. https://doi.org/10.1127/entomologia/2019/0809

Moreau, J., Villemant, C., Benrey, B., \& Thiéry, D. (2010). Species diversity of larval parasitoids of the European grapevine moth (Lobesia botrana, Lepidoptera: Tortricidae): The influence of region and cultivar. Biological Control, 54(3), 300-306. https://doi.org/10.1016/j. biocontrol.2010.05.019

Moschos, T. (2006). Yield loss quantification and economic injury level estimation for the carpophagous generations of the European grapevine moth Lobesia botrana Den. et Schiff. (Lepidoptera: Tortricidae). International Journal of Pest Management, 52(2), 141-147. https://doi. org/10.1080/09670870600639179

Nobre, T., Gomes, L., \& Rei, F. T. (2018). Uncovered variability in olive moth (Prays oleae) questions species monophyly. PLoS One, 13(11), 1-12. https://doi.org/10.1371/journal.pone.0207716

Oliver, K. M., Degnan, P. H., Burke, G. R., \& Moran, N. A. (2010). Facultative symbionts in aphids and the horizontal transfer of ecologically important traits. Annual Review of Entomology, 55, 247-266. https://doi.org/10.1146/annurev-ento-112408-085305

Pertot, I., Caffi, T., Rossi, V., Mugnai, L., Hoffmann, C., Grando, M. S., ... Anfora, G. (2016). A critical review of plant protection tools for reducing pesticide use on grapevine and new perspectives for the implementation of IPM in viticulture. Crop Protection, 97, 70-84. https://doi.org/10.1016/j.cropro.2016.11.025

Sammaritano, J. A., Deymié, M., Herrera, M., Vazquez, F., Cuthbertson, A. G. S., López-lastra, C., \& Lechner, B. (2018). The entomopathogenic fungus, Metarhizium anisopliae for the European grapevine moth, Lobesia botrana Den. \& Schiff. (Lepidoptera: Tortricidae) and its effect to the phytopathogenic fungus, Botrytis cinerea. Egyptian Journal of Biological Pest Control, 28, 83. https://doi.org/10.1186/ s41938-018-0086-4

Saridaki, A., \& Bourtzis, K. (2010). Wolbachia: More than just a bug in insects' genitals. Current Opinion in Microbiology, 13, 67-72. https:// doi.org/10.1016/j.mib.2009.11.005 
Sintupachee, S., Milne, J. R., Poonchaisri, S., Baimai, V., \& Kittayapong, P. (2006). Closely related Wolbachia strains within the pumpkin arthropod community and the potential for horizontal transmission via the plant. Microbial Ecology, 51(3), 294-301. https://doi.org/10.1007/ s00248-006-9036-x

Sumida, Y., Katsuki, M., Okada, K., Okayama, K., \& Lewis, Z. (2017). Wolbachia induces costs to life-history and reproductive traits in the moth, Ephestia kuehniella. Journal of Stored Products Research, 71, 93-98. https://doi.org/10.1016/j.jspr.2017.02.003

Thiéry, D., Louâpre, P., Muneret, L., Rusch, A., Sentenac, G., Vogelweith, F., ... Moreau, J. (2018). Biological protection against grape berry moths. A review. Agronomy for Sustainable Development, 38, 15. https://doi.org/10.1007/s13593-018-0493-7

Thiéry, D., \& Moreau, J. (2007). Relative performance of European grapevine moth (Lobesia botrana) on grapes and other hosts. Oecologia, 143(4), 548-557. https://doi.org/10.1007/s00442-005-0022-7

Xuéreb, A., \& Thiéry, D. (2006). Does natural larval parasitism of Lobesia botrana (Lepidoptera: Tortricidae) vary between years, generation, density of the host and vine cultivar? Bulletin of Entomological Research, 96, 105-110. https://doi.org/10.1079/BER2005393
Zchori-Fein, E., \& Bourtzis, K. (2011). Manipulative tenants: Bacteria associated with arthropods. Cleveland, OH: CRC Press.

Zchori-Fein, E. I., \& PerIman, S. J. (2004). Distribution of the bacterial symbiont Cardinium in arthropods. Molecular Ecology, 13(7), 20092016. https://doi.org/10.1111/j.1365-294X.2004.02203.x

Zélé, F., Weill, M., \& Magalhães, S. (2018). Identification of spider-mite species and their endosymbionts using multiplex PCR. Experimental and Applied Acarology, 74(2), 123-138. https://doi.org/10.1007/ s10493-018-0224-4

Zhou, W., \& Neill, S. O. (1998). Phylogeny and PCR-based classification of Wolbachia strains using wsp gene sequences. Proceedings of the Royal Society of London. Series B: Biological Sciences, 265(1395), 509-515. https://doi.org/10.1098/rspb.1998.0324

How to cite this article: Pazian M, Bacala E, Rei FT, Nobre T. Wolbachia is present in the European grapevine moth. J Appl Entomol. 2020;00:1-5. https://doi.org/10.1111/jen.12774 